\title{
Labors of the New American Hercules: Transatlantic Relations in the Wake of the War with Iraq
}

by Hall Gardner*

\section{I.}

Time will tell whether preemptive military intervention in Iraq has truly helped to stimulate efforts to "resolve," or even significantly change for the better, the complex crises emanating from the Persian Gulf, the Middle East, Central Asia, Africa, and the Korean peninsula, let alone helped to put in place a semblance of "communal" democracy in Iraq that can help unify its divergent ethnic and religious factions. From today's standpoint, however, U.S. relations with both major and regional powers appear much more fractious.

As the war against Iraq did not receive the stamp of international legitimacy from the United Nations Security Council, as did the U.S. intervention in Afghanistan - or at a very minimum obtain a general international consensus of approval, as did the war "over" Kosovo - the U.S.-U.K. intervention has significantly damaged U.S. relations with France, Germany, Russia, and Turkey. It has also tended to undermine the "legitimacy" of the UN and, indirectly, the "credibility" of NATO. It may have also undercut the U.S.-U.K. "special relationship." There is, furthermore, a real risk that U.S. neo-conservative policies could continue to divide an expanding Europe and force it out of its comfortable Kantian “out of history” nest on Venus (according to Robert Kagan's typol$\left.\mathrm{ogy}^{1}\right)$ and throw it once again into the "real" world of major power rivalries.

Preventing the situation from proving totally disastrous will require that Washington now engage in a much more sophisticated and innovative global strategy, one that emphasizes a truly concerted sharing of responsibility and power among the U.S., Europe, and Russia, and that utilizes a more complementary mix of diplomacy and force.

\section{II.}

The fact that in the recent past the U.S. has fought relatively brief wars in Bosnia, Kosovo, Afghanistan, and now Iraq has created a new form of "short war illusion," as well as a mirage of Herculean omnipotence. These beliefs have arisen despite the fact the "victories" themselves have been complicated by the long-term nature of the peacekeeping efforts required and the political, social,

\footnotetext{
* Hall Gardner is Professor and Chair of the Department of Political Science at the American University in Paris.

${ }^{1}$ Robert Kagan, Of Paradise and Power (New York: Knopf, 2003). Kagan describes the ideological disconnect between the U.S. and Europe in terms of Europeans being from Venus, while Americans are from Mars.
} 
and economic problems related to reconstruction that have been faced in each case.

One of the major rationales for the French and Germans to oppose preemptive intervention in Iraq was not that of "pacifism," but rather the question of what exactly would be done with a defeated, unstable, and chaotic Iraq after the war. Moreover, without any substantial "Marshall Plan" to offer Iraq, the U.S. simply could not expect the Europeans to pick up the post-war pieces without having any real say in the initial implementation of policy.

French and German disagreements with the U.S. regarding fellow NATO member Turkey represented an additional factor that helped divide the Alliance. Although blamed for instigating a major crisis within NATO for not initially agreeing to allow the provision of AWACS planes (Airborne Warning and Control System) and Patriot missiles for Turkish defense, neither France nor Germany were responsible for the Turkish refusal to support U.S. troop deployments at the outset of the war. Nor were France and Germany responsible for Turkish threats to intervene in Iraqi Kurdistan after the war.

Ankara continues to fear the rise of a relatively autonomous Kurdish state in northern Iraq, which could in turn influence Kurds in Turkey to seek independence in eastern Anatolia. Ankara's inability to reform its own relationship with the Kurds within Turkey itself could lead to greater tensions. Coupled with a reduction of the NATO presence in Turkey, the EU's refusal to accommodate Ankara's moderate Islamic leadership with some new form of EU "membership" may further isolate the country, leading it to search for new security options.

These factors indicate that the U.S.-U.K. "coalition" (officially christened in July 2003 as "occupying powers" by the UN) - or, preferably, NATO-Partnership for Peace forces under a UN mandate - will be required to maintain a long-term presence in Iraq to deal with the threat of Turkish (and/or Iranian) intervention; disputes between Kurds, Turkmen, and Arabs; conflicts among the various radical pan-Islamic Shiite factions; and the Sunni Baathist insurgency, now dubbed a "guerrilla-type war situation" by General John Abizaid. At a cost of US\$3.9 billion a month, this was not the scenario expected by "Martian" neo-conservatives, but one that French and German "Venusians" had more correctly forewarned.

\section{III.}

U.S. efforts to obtain the political and economic allegiance of Eastern European states may divide the EU even further, and, in addition, may isolate Moscow. A prime example is the $\$ 3.5$ billion sale of 48 U.S. F-16 fighters to Poland (to be delivered from 2006-8) - a sale that took place in direct competition with offerings of Swedish Gripen and French Mirage 2000-5 fighter jets, and which includes over $\$ 6$ billion in a foreign military financing (FMF) loan package, 43 
offsetting projects, and direct U.S. foreign investment. This "contract of the century" has upset French and Swedish arms producers, Germany (the major investor in Poland), as well as EU Commission President Romano Prodi. ${ }^{2}$

Ostensibly a reward for Polish support for the Iraq war, the sale of these F-16s could also have the effect of alienating Belarus and Russia. The sale is symbolic of a burgeoning military-industrial relationship between the U.S. and states in Eastern Europe, which appears to run counter to unwritten U.S. promises not to expand the NATO infrastructure into Eastern Europe. The sale of the F-16s, the deployment of 5,000 to 10,000 NATO troops in Poland, and the establishment of bases in Bulgaria and Romania, coupled with U.S. efforts to foster a Polish-Ukrainian alliance in regard to "coalition" peacekeeping in northern Iraq - not to overlook the strategic implications of U.S. unilateral withdrawal from the ABM treaty and U.S. threats to cut Russia out of the Iraqi oil market and not support its bid to enter the WTO - may, among other issues, anger anti-Western Russian nationalists and frustrate moderates.

Despite the post-September 11 NATO-Russian entente, Russia has only grudgingly accepted Baltic state membership in NATO. It has also demanded that all Eastern European states sign the outdated Conventional Forces in Europe pact before entering NATO, or else that it be revised entirely. While Moscow has thus far supported limited U.S./NATO operations in former Soviet republics in Central Asia, it has questioned the purpose of some NATO activities, particularly those affecting the Caucasus. The fact that Russia has pulled its peacekeepers out of Bosnia and Kosovo is already symbolic of its lack of continuing political support for U.S./NATO policy in these regions.

Whether NATO enlargement will, in fact, ultimately prove to be the "most fatal error of American policy in the entire post-Cold War era," as prognosticated by George Kennan, will largely depend upon the reforms taking place within NATO itself, as well as the nature of the security accords reached by NATO with both the EU, as the latter likewise expands into Eastern Europe, and with Russia. ${ }^{3}$ Moscow may be eyeing closer relations with China and India as it reluctantly cedes control over former Soviet space in both Eastern Europe and Central Asia, and looks on quite resentfully as the U.S. Hercules defeats Russian allies in Serbia and Iraq. ${ }^{4}$

\section{IV.}

While U.S. policies appear intended to divide the "old" Western and the "new" Eastern Europeans and drive a wedge between the EU and Russia, they have been countered by gradual European efforts to unify, coupled with efforts to

\footnotetext{
${ }^{2}$ REF/RL "Poland, Belarus, Ukraine" (Vol. 5, No 15, 22 April 2003).

${ }^{3}$ George F. Kennan, "A Fateful Error," New York Times, February 5, 1997, p. A19

${ }^{4}$ See my larger argument on this point in Hall Gardner, Dangerous Crossroads (Westport, CT: Praeger, 1997).
} 
cooperate more closely with Moscow.

After the failure of European diplomats to prevent the Kosovo conflict at the 1998 Rambouillet Summit (a failure, rightly or wrongly, blamed on U.S. diplomacy), the Europeans vowed to establish the so-called Euroforce. Similarly, despite U.S. efforts to play the U.K., Spain, and the Eastern European states (particularly Poland) against France and Germany, the EU opted to expand its membership to twenty-five, and the member states of the EU appear to be drawing closer together through the establishment of a single president and foreign minister.

On the one hand, the EU will need to provide significant security support to its new members. This is particularly true since Eastern European states, which will soon be members of both NATO and the EU, will only begin to fully respect EU initiatives once the EU can more truly guarantee their overall security. On the other hand, the EU will be compelled to reduce its dependence upon the U.S. as the latter begins to re-deploy some of its European bases (except Ramstein), along with 70,000 troops, away from Germany as a means to cut costs and move closer to new theaters of conflict. ${ }^{5}$

The latter was a prospect foreseen in the Clinton era, yet German opposition to the war with Iraq has been cynically used by the Bush Administration as a pretext for cutting back the U.S. military presence in Europe. In addition to weakening the core NATO relationship with Berlin already complicated by disputes over the International Criminal Court - this fact may hold unexpected political and economic consequences for U.S.-German relations, which will be magnified by the decline of the dollar relative to the Euro and other major U.S.-EU trade disputes over agriculture, aerospace, and steel subsidies, as well as over genetically modified organisms.

Contrary to U.S. expectations, the political fall-out from U.K. Prime Minister Tony Blair's decision to side with the Bush Administration in the war with Iraq (despite Blair's failed efforts to influence U.S. policy from behind the scenes) could ultimately push the U.K. closer to the EU. The U.S.-U.K. justification for so-called preemptive war, following the argument that Iraq possessed WMD and posed an imminent threat, has been seriously criticized, and the entire U.S.-U.K. "special relationship" has been put into question.

As the U.K. re-evaluates its relations with the U.S. and Europe, London seriously looks like it could join "Euroland" within the next five years,

\footnotetext{
${ }^{5}$ Greg Jaffe, "In Massive Shift, U.S. is Planning to Cut Size of Military in Germany," Wall Street Journal 10 June 2003. The U.S. not only plans to downsize its 70,000-strong troop presence in Germany, but also to deploy some 5-10,000 troops in Poland' some 15,000 in Azerbaijan (a fact seen as threatening Iran); and to increase troops in Djibouti to 5,000-6,500. Semi-permanent bases are to be maintained in Algeria, Morocco, and Tunisia, along with Senegal, Ghana, Mali, and Kenya. (It should be noted that many of these are former French colonies or protectorates). One of the primary U.S. goals in Africa is to protect Nigeria, which is expected to supply some 25 percent of U.S. oil demand in the future.
} 
despite having ruled out such a possibility in 2003. Should the U.K. ultimately take steps to move toward closer ties with the European Union, as the $1998 \mathrm{St}$. Malo initiative initially indicated, then the possibility of a European Common Foreign and Security Policy (CFSP) becomes much more plausible.

From this perspective, Europe will soon be impelled by both extra- and intra- European considerations to develop more autonomous military capabilities. Both the regional and global aspects of European diplomacy will need to be backed by the existence of a credible military force if the CFSP is to be successful.

\section{V.}

The key problem is not so much European "weakness" but the Janus-faced nature of U.S. foreign policy. On the one hand, U.S. neo-conservatives complain that the U.S. will only respect the EU once the latter truly begins to flex its muscles and take up its share of global responsibilities. (In this regard, the "Euroforce" must not remain an "empty shell.") On the other hand, the neocons have also opposed a Europe that can think and act for itself; they tend to exaggerate the future EU capacity for independent military action.

As the EU represents a new form of confederation, it is doubtful that Europe will become a "hard pole" that can wholeheartedly counterbalance the United States. Under the proposed new Constitution, foreign policy decisions will be subject to the principle of unanimity, while individual states will still retain control over their national militaries. The real problem is thus not so much that the Europeans live in a Kantian realm outside of history, but that the two-faced foreign policy of the United States - with its gates unexpectedly and selectively swinging open or shut for war or for peace - continues to insist on sharing burdens and responsibilities, but without accepting true European power-sharing.

From this perspective, rather than attempt to restrict Europe's capacity to develop a truly unified CFSP, the U.S. should work with the Europeans to establish areas of mutual complementarity given their respective military and political-economic capabilities and differing interests, even if that implies a certain degree of asset duplication.

\section{VI.}

The above points indicate that a Herculean "divide and rule" strategy could alienate both the Europeans and the Russians, at the same time that the U.S. risks military and political-economic overextension in fighting the hydra of new threats, falling into the trap set by Osama Bin Laden.

To prevent U.S. overextension, the Bush Administration should begin to internationalize the reconstruction of Iraq by formally phasing in the UN, plus NATO and Partnership for Peace forces, which may also help the Iraqi 
Governing Council obtain legitimacy and minimize policy disputes as Iraq prepares for self-rule. The Bush Administration has, however, only brought in NATO states and the UN in piecemeal ways. ${ }^{6}$ In July 2003, France, Germany, and Russia ruled out peacekeeping participation without a specific UN mandate.

If the situation in Iraq continues to deteriorate, the U.S. may be forced to bite the bullet, particularly if peacekeeping forces become stretched too thin between Afghanistan and Iraq. ${ }^{7}$ Yet in this case states that strongly opposed the war with Iraq may be asked to bite the bullet as well, something that they may find difficult. Nevertheless, they must confront the question, of whether it is possible to bring the UN totally into Iraq without tacitly granting the U.S.-U.K. intervention a post facto legitimacy ${ }^{8}$

Despite their opposition to the Iraq war, the French and Germans still play a complementary role in global peacekeeping, particularly in Afghanistan under general UN mandates. The U.S. has requested basing rights in former French colonial protectorates, which indicates the widening nature of the global security crisis. While the U.S. itself may attempt to deal with the conflict in Liberia, French-led EU actions under the UN banner in the Congo (after Ivory Coast) could represent the stepping stone to a more effective Euroforce.

The UN, U.S., EU, and Russian "Quartet" may similarly need to consider the deployment of multinational peacekeepers, involving overlapping NATO-EU-Russian security accords to guarantee both Israeli and Palestinian state security, and to prevent the Road Map for Peace from losing itself along the route. (Tony Blair had linked U.S.-U.K. intervention in Iraq to the resolution of the Israeli-Palestinian conflict as a matter of "even-handedness.")

The U.S., the EU, and Russia should also foster the formation of multilateral "contact groups" (similar to that formed to deal with Bosnia) to focus on ending "World War III" in Africa, and to work toward Indian-Pakistani reconciliation. While only Washington can resolve the current crisis with North Korea though diplomatic recognition and security guarantees for Pyongyang, the EU can help facilitate the U.S.-North Korean rapprochement through promises of aid and assistance, so as to try to prevent the onslaught of a major regional war. ${ }^{9}$

\footnotetext{
${ }^{6}$ Nine of NATO's nineteen members are already involved in the Iraq operation, but not as members of NATO.

${ }^{7}$ Nicholas Kralev, "Pullout in Afghanistan worries Germany," Washington Times, 17 July 2003.

${ }^{8}$ See also Hall Gardner, "The Iraq Crisis and Its Impact on the Future of the EU-U.S. Relations: An American View," www.cicerofoundation.org.

${ }^{9}$ The North Korean government stated that, "The Iraqi war teaches a lesson that in order to prevent a war and defend the security of a country and the sovereignty of a nation, it is necessary to have a powerful physical deterrent." Cited in Colin Robinson, "Stand-off with North Korea: War Scenarios and Consequences," Center for Defense Information website, at www.cdi.org. David Shambaugh, "China and the Korean Peninsula: Playing for the Long Term," The Washington Quarterly 26:2 (Spring 2003), p. 173. See comments by former Secretary of Defense William Perry, "U.S., North Korea Drifting Toward War,” Washington Post, 15 July 2003.
} 
Closer to home, the EU is taking over the peacekeeping role in Macedonia, and possibly Bosnia in 2004, but some doubt remains regarding Kosovo. The Dutch have proposed an EU-led OSCE peacekeeping force for Moldova, with Russian cooperation. As both NATO and the EU continue their largely uncoordinated enlargement processes, the EU needs to show its strategic-military utility in Eastern Europe, but in coordination with the Russians. In order to prevent the alienation of Russia and to enhance overall European security, the creation of regionally-based multinational security communities, backed by overlapping NATO, EU, and Russian security guarantees, can attempt to offset destabilizing factors that help produce organized crime and terrorism. ${ }^{10}$

Another point cannot be over-emphasized: NATO enlargement is, in effect, leapfrogging over key strategically-positioned EU members - ironically, the democratic states of Sweden, Finland, and Austria. This fact gives the EU some leverage to deal with the U.S., but it will mean the careful coordination of NATO-EU defense planning. Here, instead of placing a provocative NATO HQ in the Baltic states, as has been proposed, the construction of a multilateral NATO-EU-Russian peacekeeping headquarters in Kaliningrad, as symbolic of multilateral security cooperation, may actually provide a better guarantee for Baltic state security. This is because an alienated Russia, without a droit de regard, may attempt to undermine unilateral NATO efforts to guarantee security in the region.

Finally, rather than denigrating the UN, the U.S. should attempt to relegitimize it, by making the Security Council more representative of post-Cold War political-economic relations. One option is to place France and Germany, and perhaps the U.K., into one Security Council seat in a form of regional representation (assuming that Europe can truly formulate a CFSP) and bring in Japan as a permanent Security Council member. This could help provide wider representation for the second-tier non-permanent members. If more permanent members come in, then a two-veto system for the Security Council could be implemented. A more representative UN could then play a more vital role in sanctioning collective policies and in legitimizing military intervention and peacekeeping operations.

\section{VII.}

The American version of Hercules is engaging in a number of the "twelve labors" almost simultaneously. Having defeated the Lion of Nemea (the Taliban), at least in appearance, Hercules' war with the multi-headed Hydra of global terrorism - with the help of his nephew and charioteer Iolaos - continues. The U.S. has thus far failed to capture the Ceryneian Hind (Bin Laden) alive, although it may be on the trail of the Erymanthian Boar (Saddam

\footnotetext{
${ }^{10}$ See Hall Gardner, “Aligning for the Future," Harvard International Review (Winter 2003), p. 84.
} 
Hussein), having snared his two sons. But it has not been able to control the Stymphalian Birds that plague the Middle East road to peace. The new American Hercules has also not yet figured out a more clever stratagem to flush the nuclear waste from the stables of the North Korean Augeas.

Hercules was confronted with challenges that resulted in significant errors of judgment and much "collateral damage." Yet even that all-powerful mythological figure did not succeed in his twelve labors without seeking the advice of the gods (to obtain legitimacy) as well as the help of his friends. It appears, however, that the new American version may need even greater assistance than did the ancient one - with the assumption that its present friends and allies will not, in the very near future, decide to part company altogether. 


\section{Bibliography}

Gardner, Hall. "Aligning for the Future." Harvard International Review (2003): 84.

Gardner, Hall. Dangerous Crossroads. Westport, CT: Praeger, 1997.

Jaffe, Greg. "In Massive Shift, U.S. is Planning to Cut Size of Military in Germany." Wall Street Journal (2003).

Kagan, Robert. Of Paradise and Power. New York: Knopf, 2003.

Kennan, George F.. "A Fateful Error." New York Times (1997): A19.

Kralev, Nicholas. "Pullout in Afghanistan worries Germany." Washington Times (2003).

Perry, William. "U.S., North Korea Drifting Toward War." Washington Post (2003).

Shambaugh, David. "China and the Korean Peninsula: Playing for the Long Term." The Washington Quarterly 26, no. 2 (2003): 173. 